Article available at http://www.parasite-journal.org or http://dx.doi.org/10.1051/parasite/2001081045

\title{
Gallegostrongylus australis N. SP. (Nematoda: Angiostrongylidae) from Muridae in Australia, WITH ZOOGEOGRAPHICAL CONSIDERATIONS
}

\author{
SPRATT D.M.*, HAYCOCK P.* \& WALTER E.L.*
}

\begin{abstract}
Summary :
Gallegostrongylus australis n. sp. (Nematoda: Angiostrongylidae) is described from subpleural nodules in the lungs of Rattus fuscipes, R. lutreolus and Mus domesticus in Australia. It is distinguished from $G$. andersoni occurring in gerbillids in West Africa by the shorter lengths of spicules and gubernaculum, and from $G$. ibicensis occurring in microtids and murids in Spain by the greater lengths of spicules and gubernaculum and the shorter distances from vulva and from anus to the caudal extremity of females. The parasite has been found only in 16 of 4,227 (prevalence $0.38 \%$ ) animals representing at least 28 species of native and three species of introduced murid rodents throughout Australia. The genus Gallegostrongylus may be an old one, possibly originating in rats. By rafting and/or human activities the parasite appears to have been distributed around the world where it has encountered suitable intermediate hosts and available niches for colonisation of new definitive hosts. Consequently, morphologically similar but biologically distinct species have evolved in rodent hosts in West Africa, the western

Mediterranean, and Australia.
\end{abstract}

KEY WORDS : Gallegostrongylus, Nematoda, Angiostrongylidae, Muridae Australia.

\section{INTRODUCTION}

$\mathrm{N}$ odules, $2-20 \mathrm{~mm}$ in diameter, were found in the subpleura of the lungs of native bush rats, Rattus fuscipes (Waterhouse, 1839), swamp rats, Rattus lutreolus (Gray, 1841) and one wild Mus domesticus Schwartz \& Schwartz, 1943 (see Figueroa et al., 1986) trapped in Nadgee and Timbillica State Forests, approximately $30 \mathrm{~km}$ south of Eden, in southeastern New South Wales, Australia. They harboured adult nematodes, embryonating eggs and large numbers of first-stage larvae with kinked tails characteristic of the nematode superfamily Metastrongyloidea.

\footnotetext{
* CSIRO Wildlife \& Ecology, GPO Box 284, Canberra, A.C.T. 2601, Australia.

Correspondence: D.M. Spratt.

Tel.: 0262421648 - Fax: 0262421555

E-mail: David.Spratt@cse.csiro.au
}

Résumé : GALLEGOSTRONGYLUS AUSTRALIS N. SP. (NEMATODA : AngIOstrongylidae) DE MURIDÉs D'Australie. Considérations ZOOGÉOGRAPHIQUES

Gallegostrongylus australis n. sp. (Nematoda : Angiostrongylidae) est décrit au niveau de nodules pulmonaires sous pleuraux de Rattus fuscipes, R. lutreolus et Mus domesticus en Australie. II se distingue de G. andersoni observé chez les gerbilles d'Afrique de l'Ouest par la taille réduite des spicules et du gubernaculum, et de $G$. ibicensis observé chez les microtidés et les muridés en Espagne par la plus grande taille des spicules et du gubernaculum et les moindres distances entre vulve, anus et extrémité caudale chez la femelle.

Le parasite a été retrouvé chez seulement 16 des 4227 animaux (prévalence de 0,38\%) de 28 espèces natives et de trois espèces introduites de rongeurs muridés de toute l'Australie. Le genre Gallegostrongylus pourrait être ancien, importé avec les rats. Sur des radeaux de fortune et/ou avec l'activité humaine, le parasite semble ainsi s'être répandu dans différentes régions du monde où il a trouvé de nouveaux hôtes intermédiaires et définitifs. Ceci expliquerait que des espèces similaires au plan morphologique mais distinctes au plan biologique ont évolvé chez différents hôtes rongeurs d'Afrique de l'Ouest, de la Méditerranée occidentale et de l'Australie.

MOTS CLÉS : Gallegostrongylus, Nematoda, Angiostrongylidae, Muridae, Australie.

Adults of only two nematode species, Angiostrongylus cantonensis and A. mackerrasae, have been reported from the lungs of rodents in Australia (Mackerras \& Sandars, 1955; Bhaibulaya, 1968, 1974, 1975; Mesina et al., 1974) although a diverse array of nematodes occur in the lungs of marsupials (Spratt, 1979, 1980, 1981, 1984; Spratt \& Gill, 1998), some causing mild pathological changes (McColl \& Spratt, 1982; Spratt \& Gill, 1998).

The nematodes found in the pulmonary nodules of indigenous rats in New South Wales were morphologically distinct from metastrongyloid, thelazioid and muspiceoid lungworms previously recorded from rodents and marsupials in Australia (loc. cit.). However, they bore a striking similarity to Gallegostrongylus andersoni reported from the gerbillid, Taterillus nigeriae Thomas, 1911 in West Africa (Petter, 1972) (as Aelurostrongylus andersoni), and to G. ibicensis reported from the murids Mus musculus Linnaeus, 1758 and M. spretus Lataste, 1883, and the microtid Pitymys duodecimcostatus de 
1

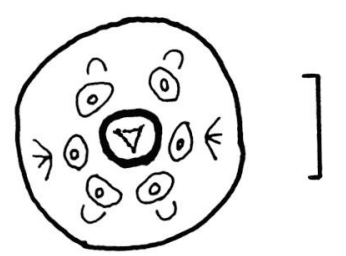

2
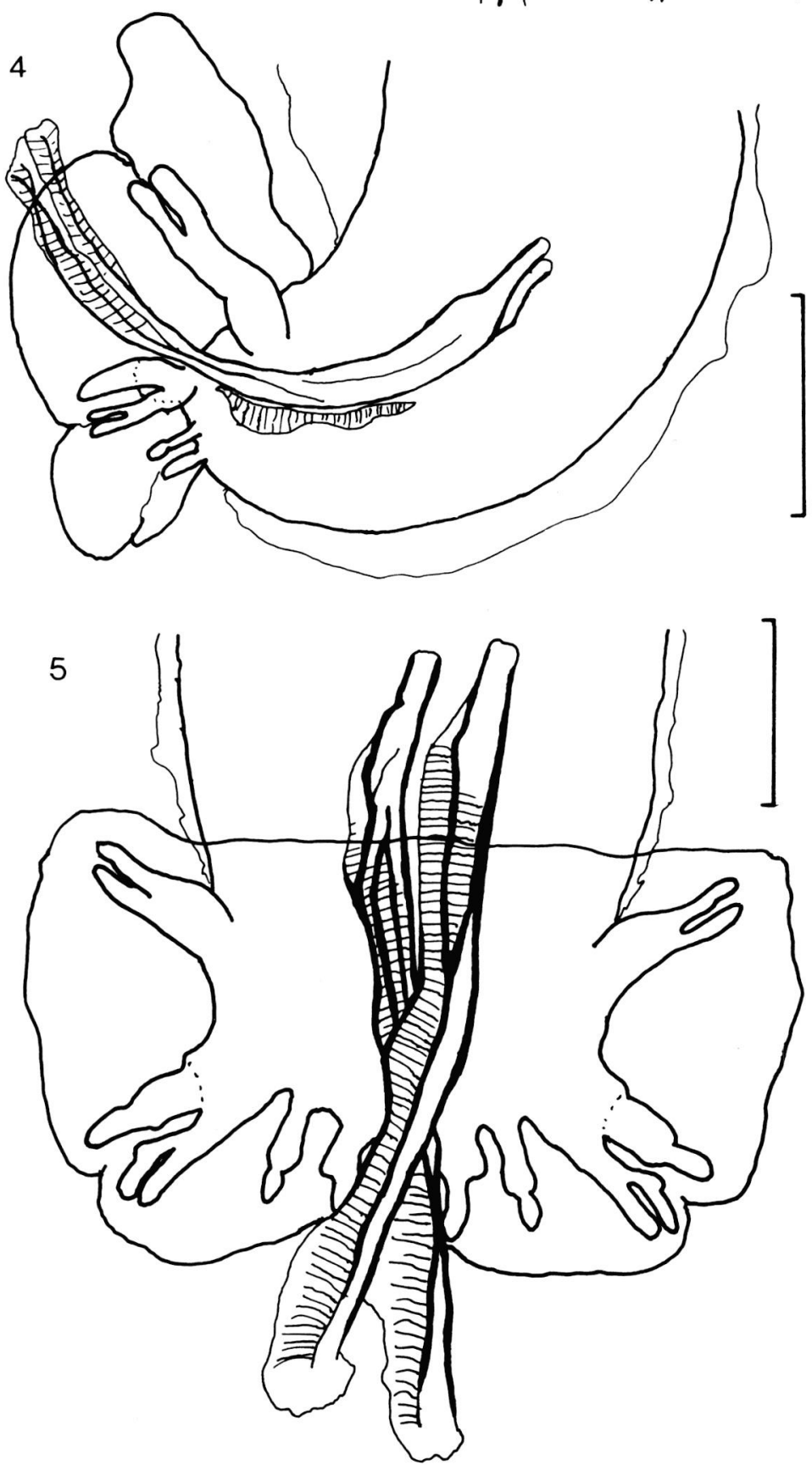
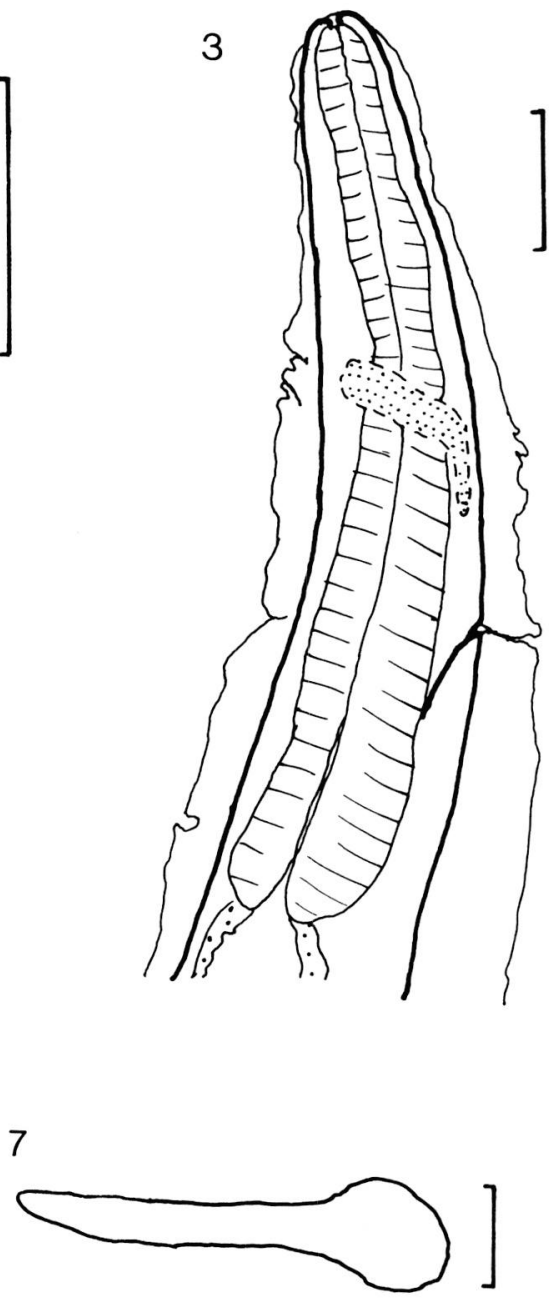

6

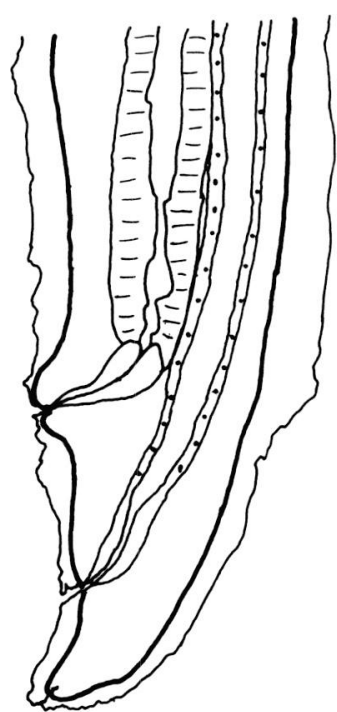

Figures 1-7. - Gallegostrongylus australis n.sp. from Rattus fuscipes. 1. Cephalic end, en face view, bar $=10 \mu \mathrm{m}$. 2. Female anterior end showing shallow buccal capsule, lateral view, bar $=30 \mu \mathrm{m}$. 3. Female anterior end, lateral view, bar $=50 \mu \mathrm{m}$. 4 . Male caudal end, lateral view, bar $=50 \mu \mathrm{m}$. 5. Male bursa and spicules, ventral view, bar $=30 \mu \mathrm{m}$. 6. Female caudal end, lateral view, bar $=50 \mu \mathrm{m} .7$. Gubernaculum, lateral view, bar $=10 \mu \mathrm{m}$. 
Sélys-Longechamps, 1839 in Spain (Mas-Coma, 1977; Mas-Coma \& Felieu, 1984).

This paper $i$ ) describes adult stages of a new species of metastrongyloid lungworm, $i$ i) provides data on prevalence, host range and geographic distribution of the parasite in murid rodents in Australia, iii) discusses zoogeographic implications of these findings.

\section{MATERIAL AND METHODS}

M urid rodents collected in many localities in Australia by ourselves and colleagues during the period 1977-1997 were examined for parasites as part of a long-term investigation of the parasite fauna of Australian animals and the effect of perturbation (e.g. wildfire) on the structure of that fauna.

Lungs were examined for helminths by pressing pulmonary tissue between glass Petrie dishes and examining under a stereomicroscope by means of transmitted light. Representative pieces of lung were fixed in $10 \%$ neutral buffered formalin, sectioned at $6 \mu \mathrm{m}$ and stained with haematoxylin and eosin for histological examination. Worms and worm fragments were recovered, using jeweller's forceps, fixed in hot $10 \%$ neutral buffered formalin, cleared in lactophenol and studied under a compound microscope.

The following abbreviations for morphological features of adult worms and larvae are used in the text:

L length of body.

MW maximum width of body excluding tegumental sheath.

NR length from cephalic extremity to nerve ring.

EP length from cephalic extremity to excretory pore.

$\mathrm{O}$ length of oesophagus.

$\mathrm{V}$ length from caudal extremity to vulva of female worm.

A length from caudal extremity to anus of female worm.

$\mathrm{T}$ length of tail, from caudal extremity to cloaca of male worms.

GP length from cephalic extremity to genital primordium of larva.

AL length from cephalic extremity to anal pore of larva.

Measurements are in micrometres unless otherwise stated, the mean followed by the range in parentheses. Means of eight measurements are given for adult worms. Drawings were made using a drawing tube.

Material collected in Australia was compared with the paratypes of Gallegostrongylus ibicensis Mas-Coma, 1977 provided by Dr Santiago Mas-Coma, Department of Parasitology, Faculty of Pharmacy, University of Barcelona. The types of Gallegostrongylus andersoni (Petter, 1972) (= Aelurostrongylus andersoni) were exa- mined at the Muséum national d'Histoire naturelle ( $\mathrm{MnHn}$ ) (No. 58BA) as well as a number of specimens used in experimental studies in Taterillus nigeriae (MnHn No. 404BA, 409BA), Tatera nigrita (MnHn No. 388BA), Meriones crassus (MnHn No. 449BA) and Mus musculus (MnHn No. 431BA) by Petter (1974).

Collection of wild animals was conducted in accordance with the legislation of State and Territory fauna authorities and under permits issued by them for scientific research.

\section{RESULTS}

GALLEGOSTRONGYLUS AUSTRALIS N. SP. (Figs 1-7)

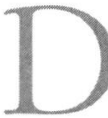
escription: Short slender nematodes with attenuated anterior extremity. Tegumental sheath present, conspicuous. Cuticle thin, with fine transverse annulations. Oral opening oval, surrounded by 6 perityles; 4 small submedian papillae present. Amphids lateral, small. Buccal cavity shallow, moderately and uniformly cuticularised. Oesophagus short, muscular, claviform. Excretory pore between nerve ring and oesophago-intestinal junction, leading into elongate, terminal excretory duct. Subventral glands long, voluminous, each with conspicuous nucleus with prominent nucleolus. Lateral alae absent.

Male. L 8.3 (7.6-9.0) mm. MW 91 (85-95) in mid-body region. NR 119 (97-142). EP 156 (150-165). O 288 (263305). Spicules similar, 141(128-150) in length and almost uniform in width, lightly sclerotised; calomus narrow and with sclerotised rods supporting membranous expansions distally, latter with fine transverse striae. Gubernaculum 51 (50-52) long, appearing as moderately thick, sclerotised rod in lateral view and without angled accessory piece extending ventrally between spicules, spoon-shaped and with long handle extending towards anterior end in ventral view. T 11 (10-12) Conspicuous genital cone present but papillae not observed. Bursa small, rays short, not stubby, ventrally curved; ventroventral and lateroventral rays partially united and arising from common trunk; anterolateral, mediolateral and posterolateral rays partially united and arising from common trunk, anterolateral ray stout and dorsal to other two rays; separated from them for more than one-half its length; mediolateral and posterolateral rays similar but smaller than anterolateral and ventral to it, united for more than one-half their length; externodorsal rays separate; dorsal ray possibly represented by two widely-separated papilliform rays each with conspicuous swelling on external surface. Cloacal papillae absent. 
Female. L 14.6 (10.3-17.9) mm. MW 123 (110-134) in mid-body region. NR 150(120-210). EP 167 (120-250). O 325 (286-390). V 89 (77-104). Vagina terminating in muscular ovejector with thick cuticular lining. Body wall forming conspicuous mound-like projections anterior and posterior to vulva. A 35 (30-41). Didelphic, prodelphic, distal uteri with eggs at early stage of embryonation. Cyst in which nematodes found containing vast numbers of eggs at all stages of embryonation as well as hatched larvae. Oviparous.

Measurements of two immature females from wild Mus domesticus. L 5.3, 5,5 mm. MW 60, 67. NR 67, 72. EP 135, 142. O 320, 350. V 87, 90. A 32, 33. Unfertilised.

Type host: Rattus fuscipes (Waterhouse, 1839).

Location in host: in subpleural nodules of the lung.

Type locality: Ludwigs Swamp, Nadgee (formerly Naghi) State Forest (NSF), $\left(37^{\circ} 17^{\prime} \mathrm{S}, 149^{\circ} 48^{\prime} \mathrm{E}\right)$ approx. $30 \mathrm{~km}$ $\mathrm{S}$ of Eden, New South Wales, Australia.

Deposition of types: Australian Helminthological Collection, South Australian Museum, Adelaide, holotype

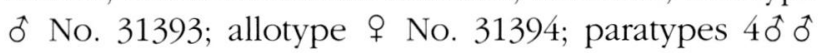
No. 31395, 5 우 No. 31396.

Other hosts: Rattus lutreolus (Gray, 1841); Mus domesticus Schwartz \& Schwartz, 1943 (see Figueroa et al., 1986).

Material examined: (all specimens collected by the authors).

From Rattus fuscipes: New South Wales, types from

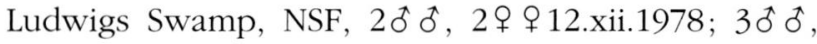

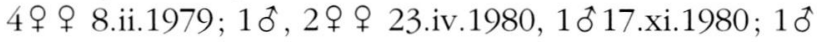
30.xi.1983; from Sidlings Swamp, Timbillica State Forest (TSF) $\left(37^{\circ} 17^{\prime} \mathrm{S}, 149^{\circ} 45^{\circ} \mathrm{E}\right)$, degenerating $\delta^{\circ} \delta$ and $q q$ 29.iii.1979.

From Rattus lutreolus: New South Wales, from Sidlings Swamp TSF, 3ठㅎ, 2 q $q$ 15.xii.1978, 1 ㅇ 25.ii.1986; Tasmania, from Mt. Barrow ( $\left.41^{\circ} 23^{\prime} \mathrm{S}, 147^{\circ} 25^{\circ} \mathrm{E}\right) 30^{\circ} \delta^{\circ}, 4 ㅇ$ 4.ii.1980.

From Mus domesticus: New South Wales, Sidling Swamp, TSF, 2 q $q$ 6.iii.1986.

Etymology: The new species is named after its geographical location in the southern hemisphere.

Diagnosis: Distinguished from other species of Gallegostrongylus by features of the spicules and gubernaculum in males and of the vulva and tail in females; from $G$. andersoni occurring in gerbillids in West Africa by the shorter lengths of spicules (141 vs 200) and gubernaculum (51 vs 70), from G. ibicensis occurring in microtids and murids in Spain by the greater lengths of spicules (141 vs 126) and gubernaculum (51 vs 43) and the shorter distances from vulva (89 vs 116) and from anus ( 35 vs 47 ) to caudal extremity of females.

\section{PREVALENCE AND HOST DISTRIBUTION IN NATURE}

A ssessment of our own data and that from previous studies of parasites of murid rodents (Bhaibulaya, 1968; Mesina et al., 1974; Glazebrook et al., 1978; Obendorf, 1979; Presidente, 1982 pers. comm; Obendorf \& Smales, 1985; Smales et al., 1990; Singleton et al., 1993; Smales \& Cribb, 1997) revealed that G. andersoni and G. ibicensis did not occur in Australia and that G. australis occurred in only 16 of 4,227 (prevalence $0.38 \%$ ) animals representing at least 28 species of native and three species of introduced murid rodents. G. australis was not found in 2 Conilurus penicillatus from Western Australia (WA), 262 Hydromys chrysogaster from Victoria (Vic), South Australia (SA), north Queensland (NQld), southeast Queensland (seQld) and Tasmania (Tas), 2 Leporillus conditor (SA), 51 Melomys burtoni (WA, Northern Territory (NT), nQld), 22 M. cf burtoni (WA), 113 M. cervinipes (WA, nQld, seQld), 10 Melomys spp. (nQld), 5 Mesembriomys gouldii (WA, NT, nQld), 18 Notomys alexis (NT), 7 N. mitchelli (SA), 3 Pogonomys mollipilosus (nQld), 3 Pseudomys delicatulus (NT), $1 P$. desertor (NT), 8 P. fuscus from montane New South Wales (NSWm), 4 P. gracilicaudatus (nQld), 44 P. hermannsburgensis (SA, NT), 12 P. higginsi (Tas), 7 P. nanus (WA, NT), 1 Pseudomys sp. \#1 (WA), 28 Rattus colletti (NT), 14 R. leucopus (nQld), 291 R. norvegicus from coastal NSW (NSWco) (Vic, nQld, seQld), 461 R. rattus (NSWco, Australian Capital Territory (ACT), Vic, nQld, seQld), 68 R. sordidus (nQld), 12 R. tunneyi (WA, NT), 16 R. villosissimus (nQld), 9 Rattus spp. (nQld), 34 Uromys caudimaculatus (nQld), 20 Zyzomys argurus (WA, NT), $10 Z$. woodwardi (WA, NT) Furthermore, G. australis is known from only three localities in southeastern Australia; two coastal locations in far southeastern New South Wales near the Victorian border - Ludwigs Swamp, Nadgee State Forest and Sidling Swamp, Timbillica State Forest, - where it was found in $R$. fuscipes and $R$. lutreolus, and on one occasion in M. domesticus-, and Mt. Barrow, Tasmania where it was found in $R$. lutreolus (Table I). R. fuscipes does not occur in Tasmania.

\section{DISCUSSION}

7 allegostrongylus andersoni and G. ibicensis - have not been found in rodent (Smales, 1997) or marsupial (Spratt et al. 1991) hosts in Aus- 


\begin{tabular}{|c|c|c|c|c|c|c|c|c|c|c|c|c|c|c|}
\hline \multirow{2}{*}{$\begin{array}{l}\text { Species } \\
\text { of murid }\end{array}$} & \multicolumn{14}{|c|}{ No. infected/No. examined } \\
\hline & NSWCO & $\mathrm{NSWm}$ & $\mathrm{NSW}_{C \mathrm{C}}$ & NSWa & ACT & VIC & SA & WA & NT & nQLD & SeQLD & TAS & sub-Antarc. & Totals \\
\hline \multirow[t]{3}{*}{ Rattus fuscipes } & $9 / 633$ & $0 / 33$ & & & $0 / 6$ & $0 / 47 \mathrm{~d}$ & & & & $\begin{array}{l}0 / 13 \\
0 / 6 b\end{array}$ & $0 / 246 a$ & & & \\
\hline & & & & & & & & & & $0 / 68 c$ & & & & \\
\hline & & & & & & $0 / 10 \mathrm{f}$ & & & & & & & & $9 / 1,062$ \\
\hline Rattus lutreolus & $5 / 270$ & & & & & & & & & $0 / 2 c$ & & $1 / 12$ & & $6 / 284$ \\
\hline \multirow[t]{2}{*}{ Mus domesticus } & $1 / 173$ & & $0 / 192$ & $0 / 3$ & $0 / 72$ & $0 / 32$ & $0 / 27$ & $0 / 6$ & $0 / 1$ & $\begin{array}{l}0 / 16 b \\
0 / 25 c\end{array}$ & $0 / 487$ & $0 / 17$ & $0 / 20$ & \\
\hline & & & & & & $0 / 282 \mathrm{e}$ & & & & & & & & $1 / 1,353$ \\
\hline
\end{tabular}

$\mathrm{a}=$ Bhaibulaya, 1968; b = Messina et al., 1974; c = Glazebrook et al., 1978; d = Obendorf, 1979; e = Singleton et al., 1993; $\mathrm{f}=$ Skerratt et al , 1995.

NSWCO = New South Wales coastal; NSWm = New South Wales montane; NSWcc $=$ New South Wales central cropping; NSWa $=$ New South Wales arid; $\mathrm{nQLD}=$ north Queensland; seQLD = southeast Queensland; sub-Antarc. $=$ sub-Antarctica.

Table I. - Occurence of Gallegostrongylus australis n. sp. in two native and an introuced murid in Australia.

tralia. While it could be argued that the low prevalence of $G$. australis $\mathrm{n}$. sp. and the relatively minor morphological differences between it and its congeners suggests an incipient species or possibly variation within either G. andersoni or G. ibicensis, four features combine to support the argument that it represents a new species i) morphology, ii) geographic distribution, iii) host distribution and iv) life history traits (Spratt et al., submitted). There are consistent morphometric differences between $G$. australis from murids in Australia and the two other known species of Gallegostrongylus. G. australis is distinguished by features of the spicules and gubernaculum in males and of the vulva and tail in females. It differs from $G$. andersoni occurring in gerbillids in West Africa by the shorter lengths of spicules (141 vs 200) and gubernaculum (51 vs 70), from G. ibicensis occurring in microtids and murids on islands in the Mediterranean and on mainland Spain by the greater lengths of spicules (141 vs 126) and gubernaculum ( 51 vs 43 ) and the shorter distances from vulva ( 89 vs 116) and from anus ( 35 vs 47 ) to the caudal extremity of females. In addition, there is a pronounced geographical separation between the three species of Gallegostrongylus.

Gallegostrongylus australis n. sp. occurs naturally in two indigenous Rattus species in Australia and has been found once in wild $M$. domesticus. Despite examination of a broad spectrum of rodent species from all States and Territories of Australia over a twenty year period the evidence demonstrates that both the host and geographical distribution of the parasite are exceptionally restricted (Table I). It is noteworthy that Mesina et al., (1974) recorded a single nematode inside a bronchiole of a murid rodent (host species not identified) in north
Queensland which they thought was Angiostrongylus cantonensis although the location was not typical because $A$. cantonensis usually is found inside pulmonary arteries or the right ventricle. Gallegostrongylus australis occurs normally in subpleural nodules in the lung parenchyma but may occur in bronchi and bronchioles.

Murid rodents constitute approximately $25 \%$ of the terrestrial mammal fauna of Australia ( Watts \& Aslin, 1981). About 7 mya, a movement of rodents from the Sundra shelf to the Indonesian archipelago and thence to Papua New Guinea (PNG) and Australia resulted in establishment of what are known as the "old indigenous" group of rodents, the Hydromyinae, in Australia. Subsequent radiation of Murinae, Rattus spp., in the Indonesian archipelago and PNG resulted in a second rodent invasion by the ancestors of $R$. fuscipes and $R$. lutreolus when the land bridge formed between PNG and Australia 1.6 to 2 mya. Speciation of these rats and of their helminth faunas then occurred in isolation on this island continent. The final rodent invasion of Australia by $R$. rattus, $R$. norvegicus, $R$. exulans and $M$. domesticus occurred relatively recently, probably from the time that Dutch exploring vessels circumnavigated the Australian continent in the 1600s to the arrival of the First Fleet from England, a little more than 200 years ago. Thus, these four species, all commensals with man, are inhabitants of probably not more than 400 years.

Man's shipping lanes have accelerated the geographical distribution of these four rodent species and presumably their parasites. Parasitologists have evaluated the parasite fauna of rodents on the islands of the Mediterranean compared with those on the mainland and concluded that (i) the parasite fauna of rodents on 
islands is generally impoverished, (ii) when parasites are found, there are a significant number of species and genera present in island rodents which do not normally occur in the same rodent species on continental areas (Mas-Coma \& Feliu, 1984; Feliu et al., 1985a, b). Consequently, insular helminths usually adapt to new hosts, that is, hosts different from the continental ones from which they originated.

Australia is a continent, but an island continent. Perhaps the genus Gallegostrongylus is a taxon which occurs patchily across the globe in the form of satellite species (Hanski, 1982). There is insufficient published data on the prevalence of $G$. andersoni and G. ibicensis in their natural host species to address this hypothesis and the exceptionally low prevalence figures for $G$. australis are not really within the scope of satellite species as defined originally by Hanski (1982). However, this same author subsequently noted that one of the predictions made by the rescue effect hypothesis is that local abundance decreases with increasing isolation of habitat patches (Hanski, 1.991). On the other hand, the lungworm, G. australis, which we have found in Australian Rattus spp. may represent a helminth brought to this country via man's activities on the shipping lanes of the world and recently adapted to new hosts where unoccupied niches were available. Human activities may not only accelerate the geographical distribution of animal species but may also play an important role in accelerating parasite speciation. The genus Gallegostrongylus may be an old one, possibly originating in rats. By rafting and/or human activities this taxon appears to have been distributed around the world where it has encountered both suitable intermediate hosts and available niches for colonisation of new definitive hosts, the phenomenon known as "hôte de capture" (Chabaud, 1965). Consequently, morphologically similar but biologically distinct species have evolved in rodent hosts in West Africa, the western Mediterranean and Australia.

\section{ACKNOWLEDGEMENTS}

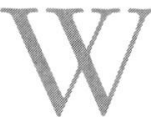
e are grateful to Drs Paul Presidente and Grant Singleton for permission to use their unpublished data from studies of murid rodents in Australia. Appreciation also is expressed to Drs. Ian Beveridge and Paul Presidente who kindly reviewed an earlier draft of the manuscript and offered valuable comments.

\section{REFERENCES}

Bhaibulaya M. A new species of Angiostrongylus in an Australian rat, Rattus fuscipes. Parasitology, 1968, 58, 789-799.
Bhaibulaya M. Experimental hybridization of Angiostrongylus mackerrasae Bhaibulaya, 1968 and Angiostrongylus cantonensis (Chen, 1935). International Journal for Parasito$\log$, 1974, 4, 567-573.

Bhaibulaya M. Comparative studies on the life history of Angiostrongylus mackerrasae Bhaibiulaya, 1968 and Angiostrongylus cantonensis (Chen, 1935). International Journal for Parasitology, 1975, 5, 7-20.

Chabaud A.G. Spécificité parasitaire. I. Chez les Nématodes parasites de Vertébrés. in Traité de Zoologie. Grassé P.P. (ed.), Masson et Cie., Paris, 1965, Vol 4, 548-564

Feliu C., Mas-Coma S. \& Gallego J. Coneixements actuals sobre l'helmintofauna paràsita dels múrids (Rodentia) a Catalunya. Butlleti de la Institutcio Catalana d'Historia Natural, 1985a, 50, 255-261.

Feliu C., Torres J., Gallego J., Gosalbez J. \& Ventura J. Primeros datos acerca de la helmintofauna de los roedores del Delta del Ebro (Peninsula Ibérica). Miscellània Zoològica, 1985b, 9, 55-64.

Figueroa F., Tichy H., McKenzie I., Hämmerling U. \& Klein J. Polymorphism of lymphocyte antigens-encoding loci in wild mice. Current Topics in Microbiology and Immunology, 1986, 127, 229-235.

Glazebrook J.S., Campbell R.S.F., Hutchinson G.W. \& Stallman N.D. Rodent zoonoses in North Queensland: the occurrence and distribution of zoonotic infections in North Queensland rodents. Australian Journal of Experimental Biology and Medical Science, 1978, 56, 147-156.

Hanski I. Dynamics of regional distribution: the core and satellite species hypothesis. Oikos, 1982, 38, 210-21.

Hanski I. Reply to Nee, Gregory and May. Oikos, 1991, 62, 8889.

Mackerras M.J. \& Sandars D.F. The life history of the rat lungworm, Angiostrongylus cantonensis (Chen). Australian Journal of Zoology, 1955, 3, 1-25.

Mas-Coma S. Gallegostrongylus ibicensis n. gen., n. sp. (Nematoda: Metastrongylidae), parasite pulmonaire de Mus musculus Linnaeus, 1758 (Rodentia: Muridae) à Ibiza (Baléares). Annales de Parasitologie Humaine et Comparée, 1977, 52, 637-642.

Mas-Coma S. \& Feliu C. Helminthfauna from small mammals (Insectivores and Rodents) on Pityusic Islands. in: Kuhbier H., Alcover J.A. \& D'Arellano Tur C.G, (eds.) Biography and Ecology of the Pityusic Islands. W. Junk, The Hague, 1984, 469-525.

McColl K.A. \& Spratt D.M. Parasitic pneumonia in a koala (Phascolarctos cinereus). Journal of Wildlife Diseases, 1982, $18,511-512$.

Mesina J.E., Campbell R.S.F., Glazebrook J.S., Copeman D.B. \& Johnson R.H. The pathology of feral rodents in North Queensland. Tropenmedizin und Parasitologie 1974, 25, 116-127.

Obendorf D.L. The helminth parasites of Rattus fuscipes (Waterhouse) from Victoria, including description of two new nematode species. Australian Journal of Zoology 1979, 27. 867-879. 
Obendorf D.L. \& Smales L.R. The internal parasites and pathological findings in Hydromys chrysogaster (Muridae: Hydromyinae) from Tasmania. Australian Journal of Zoology, 1985, 33, 33-38.

Petter A.J. Description d'une nouvelle espèce d'Aelurostrongylus parasite de Rongeur africain. Annales de Parasitologie Humaine et Comparée, 1972, 47, 131-137.

Singleton G.R., Smith A.L., Shellam G.R., Fitzgerald N. \& Müller W.J. Prevalence of viral antibodies and helminths in field populations of house mice (Mus domesticus) in southeastern Australia. Epidemiology and Infection 1993, 110, 399-417.

Skerratt L.F., Beveridge I. \& Durette-Desset M.-C. Distribution of species of trichostrongyloid nematode parasites in the small intestine of the bush rat, Rattus fuscipes. Transactions of the Royal Society of South Australia, 1995, 119, 143-148.

Smales L.R. A review of the helminth parasites of Australian rodents. Australian Journal of Zoology, 1997, 45, 505-521.

Smales L.R. \& Cribb T.H. Helminth parasite communities of the water-rat, Hydromys chrysogaster, from Queensland. Wildlife Research, 1997, 24, 445-457.

Smales L.R., Miller A.K. \& Obendorf D.L. Parasites of the water rat, Hydromys chrysogaster, from Victoria and South Australia. Australian Journal of Zoology, 1990, 37, 657-663.

Spratt D.M. A taxonomic revision of the lungworms (Nematoda: Metastrongyloidea) from Australian marsupials. Australian Journal of Zoology, 1979, Supplementary Series No. 67, 1-45.

Spratt D.M. Metathelazia naghiensis sp. n. (Nematoda; Pneumospiruridae) from the long-nosed bandicoot, Perameles nasuta (Marsupialia). Journal of Parasitology, 1980 (issued in 1981), 66, 1032-1035.

Spratt D.M. Antechinostrongylus disgubernaculus gen. et sp. n. (Nematoda: Angiostrongylidae) from the marsupial mouse, Antechinus swainsonii (Marsupialia, Dasyuridae). Journal of Parasitology, 1981, 67, 90-93.

Spratt D.M. Further studies of the lung parasites (Nematoda) from Australian marsupials. Australian Journal of Zoology, 1984, 32, 283-310.

Spratt D.M. \& Gill P.A. Durikainema phascolarcti sp. nov. (Muspiceoidea: Robertdollfusidae) from the pulmonary arteries of the koala, Phascolarctos cinereus, and associated pathological changes. Systematic Parasitology, 1998, 39, 101-106.

Spratt D.M., Beveridge I \& Walter E.L. A catalogue of Australasian monotremes and marsupials and their recorded helminth parasites. Records of the South Australian Museum, 1991, Monograph Series No. 1, 1-105.

Spratt D.M., Haycock P. \& Walter E.L. Life history and pathogenesis of Gallegostrongylus australis (Nematoda: Angiostrongylidae) in Muridae. Parasite (submitted).

Thienpont D., Rochette F. \& Vantarijs O.F.J. Diagnosing helminthiasis through coprological examination. Janssen Research Foundation, Beerse, Belgium, 1979, 1-187.

Watts C.H.S. \& Aslin H.J. The Rodents of Australia. Angus and Robertson, Sydney, 1981, 1-321.

Reçu le 12 septembre 2000 Accepté le 19 décembre 2000 